\title{
Asuhan Keperawatan Jiwa Dengan Masalah Risiko Perilaku Kekerasan Pada Penderita Skizofrenia: Studi Kasus
}

\section{Nurhayaty Pangaribuan}

\author{
nurhayaty120598@gmail.com
}

\section{BAB 1}

\section{PENDAHULUAN}

\subsection{Latar Belakang}

Gangguan jiwa juga merupakan pola perilaku atau psikologis yang di tunjukkan oleh pasien yang menyebabkan distress, disfungsi, dan menurunkan kualitas hidup. Hal ini mencerminkan disfungsi psikologis dan bukan sebagian akibat dari penyimpangan sosial atau konflik dengan masyarakat. Gangguan jiwa berat adalah gangguan yang di tandai oleh tergangguanya kemampuan menilai realistis atau tilikan (insight) yang buruk. Permasalahan yang sering terjadi pada pasien skizofrenia adalah Risiko perilaku kekerasan (Suerni, 2019).

Skizofrenia adalah sekelompok gangguan psikotik dengan distrosi khas proses piker, kadang-kadang mempunyai perasaan bahwa dirinya sedang dikendalikan oleh kekuatan dari luar dirinya, waham yang kadang-kadang aneh, gangguan persepsi, afek abnormal yang terpadu dengan situasi nyata atau sebenarnya, dan autisme. Skizofrenia merupakan gangguan psikotik yang paling sering atau hampir $1 \%$ penduduk didunia menderita skizofrenia selama hidup mereka. Gejala yang biasa muncul pada usia remaja akhir atau dewasa muda (Zahnia, 2016).

Skizofrenia suatu gangguan jiwa yang bersifat berat dan kronis yang menyerang 20 juta orang di seluruh dunia (WHO, 2019). Menurut ECA (2021) Prevelensi Amerika Serikat askizofrenia telah meningkat dari 30\% jiwa. Sedangkan Provinsi Sumatera Utara berada pada posisi ke 21 dengan 
privalensi 6,3\% (Kemenkes, 2019). Tanda dan gejala yang sering timbul akibat skizofrenia berupa gejala positif dan negatif seperti perilaku kekerasan.

Risiko perilaku kekerasan adalah salah satu respon marah yang diespresikan dengan melakukan ancaman, mencederai diri sendiri maupun orang lain. Pada aspek fisik tekanan darah meningkat, denyut nadi dan pernapasan meningkat, marah, mudah tersinggung, mengamuk dan bisa mencederai diri sendiri. Perubahan pada fungsi kognitif, fisiologis, afektif, hingga perilaku dan sosial hingga menyebabkan Risiko perilaku kekerasan. Berdasarkan data tahun 2017 dengan Risiko perilaku kekerasan sekitar 0,8\% atau dari 10.000 orang menunjukkan Risiko perilaku kekerasan sanggatlah tinggi (Pardede, Siregar, \& Halawa, 2020). Risiko perilaku kekerasan timbul akibat rasa tidak nyaman dan panik yang terjadi akibat stressor dari dalam dan luar lingkungan. Perilaku kekerasan yang timbul pada klien skizofrenia diawali dengan adanya perasaan tidak berharga, takut dan ditolak oleh lingkungan sehingga individu akan menyingkir dari hubungan interpersonal dengan orang lain (Azis, 2018).

Perilaku kekerasan yang terjadi pada pasien gangguan jiwa memiliki batasan karakteristik yng berbeda-beda (Hasannah, 2019). Risiko mencederai merupakan suatu tindakan yang memungkinkan dapat melukai atau membahayakan diri sendiri, orang lain, dan lingkungan sehingga masalah yang terjadi pada pasien parilaku kekerasan akan melibatkan keluarga (Suryenti, 2017).

Pada Survei awal ini dilakukan di Rumah Sakit Jiwa Prof. Dr. Muhammad Ildrem Diruangan Dolok Sanggul I yang berjumlah 19 dengan diagnosa medis Skizofrenia dan 3 orang yang dengan masalah keperawatan jiwa Risiko perilaku kekerasan, subjek di dalam pembuatan asuhan keperawatan ini diambil 1 orang dengan pasien Risiko perilaku kekerasan atas nama inisial Tn. H Penyebabnya Tn. H di jadikan sebagai subjek dikarenakan 
pasien belum bisa mengatasi emosinya selain meminum obat. Bedasarkan survey awal yang didapat penulis tertarik untuk memberikan asuhan keperawatan jiwa pada pasien $\mathrm{Tn}$. $\mathrm{H}$ dengan masalah Risiko perilaku kekerasan di ruang dolok sanggul I

\subsection{Rumusan Masalah}

Berdasarkan masalah yang telah di paparkan pada latar belakang maka rumusan masalah ini yaitu dapat memberikan Asuhan Keperawatan jiwa pada Tn, H dengan masalah Risiko Perilaku Kekerasan di RSJ Prof. Dr. Muhammad Ildrem.

\subsection{Tujuan}

\subsubsection{Tujuan Umum}

Mahasiswa mampu memberikan asuhan keperawatan secara holistik dan komprehensif kepada $\mathrm{Tn}$. $\mathrm{H}$ dengan risiko perilaku kekerasan di Rumah Sakit Jiwa Prof. Dr. Muhammad Ildrem di ruangan Dolok Sanggul I

\subsubsection{Tujuan Khusus}

1. Mahasiswa mampu melakukan pengkajian pada Tn. $H$ dengan gangguan Risiko perilaku kekerasan.

2. Mahasiswa mampu melakukan menegakkan diagnosa pada Tn. H dengan gangguan Risiko perilaku kekerasan.

3. Mahasiswa mampu melakukan menetapkan perencanaan pada Tn. $\mathrm{H}$ dengan gangguan Risiko perilaku kekerasan.

4. Mahasiswa mampu melakukan implementasi pada Tn. H dengan gangguan Risiko perilaku kekerasan.

5. Mahasiswa mampu melakukan evaluasi pada Tn. $H$ dengan gangguan Risiko perilaku kekerasan.

6. Mampu mendokumentasikan hasil asuhan keperawatan pada Tn. H dengan masalah Risiko Perilaku Kekerasan 
BAB 2

\section{LANDASAN TEORI}

\subsection{Risiko Perilaku Kekerasan}

\subsubsection{Defenisi}

Perilaku kekerasan merupakan suatu kemarahan yang diekspresikan oleh individu secara berlebihan sehingga tidak dapat dikendalikan baik secara verbal maupun non verbal dan dapat mencederai diri, orang lain serta merusak lingkungan. Perilaku kekerasan yang terjadi pada pasien gangguan jiwa memiliki batasan karakteristik yng berbeda-beda (Hasannah, 2019).

Perilaku kekerasan adalah suatu bentuk perilaku yang bertujuan melukai seseorang secara fisik maupun psikologis dapat terjadi dalam dua bentuk yaitu saat berlangsung kekerasan atau riwayat perilaku kekerasan. Perilaku kekerasan merupakan respon maladaptif dari marah akibat tidak mampu klien untuk mengatasi stressor lingkungan yang dialaminya (Estika, 2021).

\subsubsection{Tanda dan Gejala}

Tanda dan gerjala perilaku kekerasan adalah muka merah, tegang, mata melotot/pandangan tajam, bicara kasar, nada suara tinggi, membentak, kata-kata kotor, ketus, memukul benda/orang lain, menyerang orang lain, merusk lingkungan, amuk/agresif, jengkel, tidak berdaya, bermusuhan, mengamuk, ingin berkelahi, cerewet, kasar, berdebat, menyinggung perasaan orang lain, tidak peduli, kasar, penolakan, kekerasan, ejekan dan sindiran (Estika, 2021).

Tanda dan gejala perilaku kekerasan berdasarkan standar asuhan keperawatan jiwa dengan masalah Risiko perilaku kekerasan, (Pardede, Siregar, \& Halawa, 2020) : 


\section{Subjektif}

a. Mengungkapkan perasaan kesal atau marah.

b. Keinginan untuk melukai diri sendiri, orang lain dan lingkungan.

c. Klien suka membentak dan menyerang orang lain.

\section{Objektif}

a. Mata melotot/pandangn tajam.

b. Tangan mengepal dan Rahang mengatup.

c. Wajah memerah.

d. Postur tubuh kaku.

e. Mengancam dan Mengumpat dengan kata-kata kotor.

f. Suara keras.

g. Bicara kasar, ketus.

h. Menyerang orang lain dan Melukai diri sendiri/orang lain.

i. Merusak lingkungan.

j. Amuk/agresif.

\subsubsection{Etiologi}

Penyebab dari perilaku kekerasan bukan terdiri cuman satu faktor tetapi termasuk juga faktor keluarga, media, teman, lingkungan, biologis. Perilaku kekerasan dapat menimbulkan dampak seperti gangguan psikologis, merasa tidak aman, tertutup, kurng percaya diri, resiko bunuh diri, depresi, harga diri rendah, ketidak berdayaan, isolasi sosial (Putri, 2020).

Faktor predisposisi yang menyebabkan terjadinya skizofrenia meliputi biologis, psikologis, dan sosialkultural, dimana faktor biologis yang mendukung terjadinya skizofrenia adalah genenitk, neuroanotomi, neurokimia, dan imunovirologi. Faktor presipitasi merupakan faktor stressor yang menjadikan klien mengalami sikizofrenia yang terdiri dari faktor biologi, psikologi, dan 
sosiokultural yang mampu menyebabkan risiko perilaku kekerasan, halusinasi, dan harga diri rendah (Pardede, Keliat \& wardani 2013).

Penyebab pasien beresiko untuk melakukan perilaku kekerasan disebabkan oleh cemas secara terus menerus, untuk itu dibutuhkan strategi preventif untuk mencegah perilaku kekerasan yang salah satunya adalah dengan melakukan teknik relaksasi. Terknik relaksasi merupakan salah satu yang sering digunakan untuk menghilangkan stress ialah Muscle Relaxation Therapy (PMRT). Terapi ini mudah di pelajari dan tidak terbatas, dampaknya bisa menggurangi kecemasan dan depresi, peningkatan perasaan kontrol diri dan peningkatan kemampuan koping dalam situasi stress (Pardede, Simanjuntak \& Laia, 2020). Faktor psikologis yang menyebabkan pasien mengalami perilaku kekerasan antara lain yaitu : Keperibadian yang tertutup, kehilangan, aniaya seksual, kekerasan dalam keluarga (Pardede, Siregar, \& Halawa, 2020).

\subsubsection{Faktor Predisposisi}

1. Faktor Psikologis

Psyschoanalytical Theory : Teori ini mendukung bahwa perilaku agresif merupakan akibat dari instinctual drives. Pandangan psikologi mengenai perilaku agresif mendukung pentingnya peran dari perkembana predisposisi atau pengalaman hidup. Beberapa contoh dari pengalaman hidup tersebut :

a. Kerusakan otak organik dan retardasi mental sehingga tidak mampu menyelesaikan secara efektif.

b. Rejeksi yang berlibihan saat anak-anak.

c. Terpapar kekerasan selama masa perkembangan. 
2. Faktor Sosial Budaya

Sosial Learning Theory, ini merupakan bahwa agresif tidak berbeda dengan respon-respon yang lain, kultural dapat pula mempengaruhi perilaku kekerasan.

3. Faktor biologis

Neurotransmeiter yang sering dikaaitkan perilaku agresif dimana faktor pendukunya adalah masa kadankanak yang tidak menyengkan, sering mengalami kegagalan, kehidupan yang penuh tindakan agresif dan lingkungan yang tidak kondusif.

4. Perilaku

Reinfocemnt yang terima pada saat melakukan kekerasan dan sering mengobservasi kekerasan di rumah atau di luar rumah, semua aspek ini menstimulasi individu mengadopsi perilaku kekerasan.

\subsubsection{Faktor Presitipasi}

Ketika seseorang merasa terancam terkadang tidak menyadari sama sekali apa yang menjadi sumber kemarahannya. Tetapi secara umum, seseorang akan mengerluarkan respon marah apabila merasa dirinya terancam. Faktor presipitasi bersumber dari klien, lingkungan, atau interaksi dengan orang lain. Faktor yang mencetuskan terjadinya perilaku kekerasan terbagi dua, yaitu (Parwati, 2018) :

a. Klien : Kelemahan fisik, keputusasaan, ketidak berdayaan, kurang percaya diri.

b. Lingkungan : Ribut, kehilangan orang atau objek yang berharga, konflik interaksi sosial. 


\subsubsection{Penatalaksanaan}

Penatalaksaan perilaku kekerasan bisa juga dengan melakukan terapi restrain. Restrain adalah aplikasi langsung kekuatan fisik pada individu, tanpa injin individu tersebut, untuk mengatasi kebebasan gerak, terapi ini melibatkan penggunaan alat mekanis atau manual untuk membatasi mobilitas fisik pasien. Terapi restrain dapat diindikasikan untuk melindungi pasien atau orang lain dari cidera pada saat pasien lagi marah ataupun amuk (Hastuti, 2019).

Penanganan yang dilakukan untuk mengontrol perilaku kekerasan yaitu dengan cara medis dan non medis. Terapi medis yang dapat di berikan seperti obat antipsikotik adalah Chlorpoazine (CPZ), Risperidon (RSP) Haloperidol (HLP), Clozapin dan Trifluoerazine (TFP). Untuk terapi non medis seperti terapi generalis,untuk mengenal masalah perilaku kekerasan serta mengajarkan pengendalian amarah kekerasan secara fisik : nafas dalam dan pukul bantal, minum obat secara teratur, berkomunikasi verbal dengan baik-baik, spritual : beribadah sesuai keyakinan pasien dan terapi aktivitas kelompk (Estika, 2021).

\subsubsection{Terapi Medis}

Fsikomarmaka adalah terapi menggunakan obat dengan tujuan untuk mengurangi atau menghilanggan gejala gannguan jiwa. Dengan demiakian kepatutan mium obat adalah mengonsumsi obat yang direspkan oleh dokter pada waktu dan dosis yang tepat karena pengobatan hanya akan efektif apabila penderita memenuhi aturan dalam penggunaan obat (Pardede, Keliat, \& Yulia,2015).

\subsubsection{Tindakan Keperawatan}

Mengajarkan stimulasi persepsi perilaku kekerasan berdasarkan standar pelaksanaan untuk mengenal 
penyebab perilaku kekerasan dengan latihan fisik seperti : Tarik nafas dalam dan pukul kasur bantal, meminum obat dengan teratur, berbicara secara baik-baik seperti meminta sesuatu dan mengajarkan spritual sesuai kepercayaan pasien (Pardede, Keliat, \& Yulia,2020).

\subsection{Konsep Asuhan Keperawatan}

Pemberian asuhan keperawatan merupakan proses traupetik yang melibatkan hubungan kerjasama antara perawat dengan klien, keluarga atau masyarakat untuk mencapai tingkat kesehatan yang optimal. Tindakan asuhan keperawatan yang dilakukan berupa tindakan generalis meliputi dari pengkajian, diagnosa keperawatan, intervensi keperawatan, implementasi keperawatan, dan evaluasi keperawatan (Makhruzah, 2021).

\subsubsection{Pengkajian}

1. Identitas

Nama, umur, jenis kelamin, No MR, tanggal masuk RS, tangal pengkajian.

2. Alasan masuk

Biasanya klien masuk dengan alasan sering mengamuk tanpa sebab, memukul, membanting, mengancam, menyerang orang lain, melukai diri sendiri, mengganggu lingkungan, bersifat kasar dan pernah mengalami gangguan jiwa dimasa lalu kambuhkarena tidak mau minum obat secara teratur (Keliat,2016).

3. Faktor Predisposisi

a. Biasanya klien pernah mengalami gangguan jiwa pada masa lalu dan pernah dirawat atau baru pertama kali mengalami gangguan jiwa (Parwati, 2018).

b. Biasanya klien berobat untuk pertama kalinya kedukun sebagai alternative serta memasung dan bila tidak berhasil 
baru di bawa kerumah sakit jiwa

c. Trauma. Biasnya klien pernah mengalami atau menyaksikan penganiayaan fisik, seksual, penolakan, dari lingkungan.

d. Biasanya ada anggota keluarga yang mengalami gangguan jiwa, kalau ada hubungan dengan keluarga, gejala, pengobatan dan perawatan.

e. Biasanya klien pernah mengalami pengalaman masa laluyang tidak menyenangkan misalnya, perasaan ditolak, dihina, dianiaya, penolakan dari lingkungan

4. Pengkajian Fisik

a. Ukur dan observasi tanda-tanda vital seperti tekanan darah akan bertambah naik, nadi cepat, suhu, pernapasan terlihat cepat.

b. Ukur tinggi badan dan berat badan.

c. Yang kita temukan pada klien dengan prilaku kekerasan pada saat pemeriksaan fisik (mata melotot, pandangan tajam, tangan mengepal, rahang mengatup, wajah memerah)

d. Verbal (mengancam, mengupat kata-kata kotor, berbicara kasar dan ketus).

5. Psikososial

a. Genogram

Genogram dibuat 3 generasi keatas yang dapat menggambarkan hubungan klien dengan keluarga. Tiga generasi ini dimaksud jangkauan yang mudah diingat oleh klien maupu keluarg apa dasaat pengkajian.

b. Konsep diri

Biasanya ada anggota tubuh klien yang tidak disukai klien yang mempengaruhi keadaan klien saat berhubungan dengan orang lain sehingga klien merasa terhina, diejek dengan kondisinya tersebut.

c. Identitas

Biasanya pada klien dengan prilaku kekerasan tidak puas 
dengan pekerjaannya, tidak puas dengan statusnya, baik disekolah, tempat kerja dan dalam lingkungan tempat tinggal

d. Harga diri

Biasanya klien dengan risiko prilaku kekerasan hubungan dengan orang lain akan terlihat baik, harmoni sata terdapat penolakan atau klien merasa tidak berharga, dihina, diejek dalam lingkungan keluarga maupun diluar lingkungan keluarga.

e. Peran diri

Biasanya klien memiliki masalah dengan peranatau tugas yang diembannya dalam keluarga, kelompok atau masyarakat dan biasanya klien tidak mampu melaksanakan tugas dan peran tersebut dan merasa tidak berguna.

f. Ideal diri

Biasanya klien memilki harapan yang tinggi terhadap tubuh, posisi dan perannya baik dalam keluarga, sekolah, tempat kerja dan masyarakat.

6. Hubungan sosial

a. Orang yang berarti Tempat mengadu, berbicara

b. Kegiatan yang diikuti klien dalam masyarakat dan apakah klien berperan aktif dalam kelompok tersebut

c. Hambatan dalam berhubungan dengan orang lain/tingkat keterlibatan klien dalam hubungan masyarakat

7. Spiritual

a. Nilai dan keyakinan

Biasanya klien mengatakan bahwa dia tidak mengalami gangguan jiwa.

b. Kegiatan ibadah

Biasaya dalam selama sakit klien jarang melakukan ibadah.

8. Status mental

a. Penampilan.

Biasanya penampilan klien kotor. 
b. Pembicaraan.

Biasanya pada klien prilaku kekerasan pada saat dilakukan pengkajian bicara cepat,keras, kasar, nada tinggi dan mudah tersinggung.

c. Aktivitas motorik

Biasanya aktivitas motoric klien dengan prilaku kekerasan akan terlihat tegang, gelisah, gerakan otot muka berubahubah, gemetar, tangan mengepal, dan rahang dengan kuat.

d. Alam perasaan

Biasanya akan merasa sedih dan menyesali apa yang telah dilakukan

e. Efek

Biasanya klien mudah tersinggung dan sering marah-marah tanpa sebab

f. Interaksi selama wawancara

Biasanya klien dengan risiko prilaku kekerasan akan terlihat bermusuhan, curiga, tidak kooperatif, tidak mau menatap lawan bicara dan mudah tersinggung.

g. Persepsi

Biasanya klien dengan prilaku kekerasan masih dapat menjawab pertanyaan dengan jelas

h. Isi Pikir

i. Biasanya klien meyakini dirinya tidak sakit, dan baik-baik saja.

j. Tingkat kesadaran

k. Biasanya klien prilaku kekerasan kadang tampak bingung,

1. Memori

m. Biasanya klien diwaktu wawancara dapat mengingat kejadian yang terjadi dan mengalami gangguan daya ingat jangka panjang.

n. Kemampuan penilaian

o. Biasanya klien mengalami kemampuan penilaian ringan dan 
sedang dan tidak mampu mengambil keputusan

p. Daya fikir diri

q. Biasanya klien mengingkari penyakit yang dideritanya

9. Kebutuhan persiapan pulang

a. Makan

b. Biasanya klien tidak mengalami perubahan

c. $\mathrm{BAB} / \mathrm{BAK}$

d. Biasanya klien dengan risiko prilaku kekerasan tidak ada gangguan

e. Mandi

f. Biasanya klien jarang mandi, tidak menyikat gigi, jarang mencuci rambut dan bercukur atau berhias. Badan klien sangat bau dan kotor, dan klien hanya melakukan kebersihan diri jika disuruh.

g. Berpakaian

h. Biasanya klien jarang mengganti pakaian, dan tidak mau berdandan. Klien tidak mampu mengenakan pakaian dengan sesuai dan klien tidak mengenakan alas kaki

i. Istirahat dan tidur

j. Biasanya klien tidak melakukan persiapan sebelum tidur, seperti: menyikat gigi, cucu kaki, berdoa. Dan sesudah tidur seperti: merapikan tempat tidur, mandi atau cuci muka dan menyikat gigi. Frekuensi tidur klien berubah-ubah, kadang nyenyak dan kadang gaduh atau tidak tidur.

k. Penggunaan obat

Biasanya klien mengatakan minum obat 3 kali sehari dan klien tidak mengetahui fungsi obat dan akibat jika putus minum obat.

1. Pemeliharaan kesehatan

Biasanya klien tidak memperhatikan kesehatannya, dan tidak 
peduli tentang bagaimana cara yang baik untuk merawat dirinya.

m. Aktifitas didalam rumah

Biasanya klien mampu merencanakan, mengolah, dan menyajikan makanan, merapikan rumah, mencuci pakaian sendiri dan mengatur biaya sehari-hari.

10. Mekanisme koping

Biasanya klien menggunakan respon maldaptif yang ditandai dengan tingkah laku yang tidak terorganisir, marah-marah bila keinginannya tidak terpenuhi, memukul anggota keluarganya, dan merusak alat-alat rumah tangga.

11. Masalah psikologis dan lingkungan

Biasanya klien merasa ditolak dan mengalami masalah interaksi dengan lingkungan

12. Pengetahuan

Biasanya klien dengan prilaku kekerasan kurang pengetahuan tentang penyakitnya,dan klien tidak mengetahui akibat dari putus obat dan fungsi Dari obat yang diminumnya.

\subsection{Diagnosa Keperawatan}

Berdasarkan pohon masalah dari teori (Nursali, 2018) bahwa perilaku kekerasan disebabkan oleh halusinasi pendengaran, akan berakibat resiko mencederai diri sendiri dan orang lain, dan lingkungan, darihalusinasi dapat berakibat terjadi mencedarai orang 12 lain. Diagnosa keperawatan yang muncul pada klien dengan perilaku kekerasan, halusinasi pendengaran, isolasi sosial dan harga diri rendah. 


\subsection{Intervensi Keperawatan}

Rencana tindakan keperawatan pada klien dengan diagnosa gangguan persepsi sensori Risiko perilaku kekerasan meliputi pemberian tindakan keperawatan berupa terapi (Fadillah, 2021) yaitu :

1. Mengontrol perilaku kekerasan dengan cara tarik nafas dalam dan memukul kasur/ bantal

2. Minum obat secara teratur.

3. kontrol perilaku kekerasan dengan cara berbicara baik- baik

4. spiritual

Strategi pelaksanaan pasien dengan risiko perilaku kekerasan ada 4 cara antara lain SP 1 (identifikasi penyebab, tanda-tanda, jenis perilaku kekerasan yang dilakukan dan latihan cara mengontrol perilaku kekerasan secara fisik : tarik nafas dalam dan pukul kasur bantal), SP 2 (Latihan minum obat), SP 3 (Latihan secara verbal 3 cara yaitu mengungkapkan, meminta, dan menolak denganbenar), SP 4 (Latihan cara mengontrol perilaku kekerasan dengan berdoa).

\subsection{Implementasi Keperawatan}

Implementasi disesuaikan dengan rencana tindakan keperawatan. Pada situasi nyata sering pelaksanaan jauh berbeda dengan rencana, hal ini terjadi karena perawat belum terbiasa menggunakan rencana tertulis dalam melaksanakan tindakan keperawatan. Sebelum melaksanakan tindakan keperawatan yang sudah direncanakan, perawat perlu memvalidasi dengan singkat apakah rencana tindakan masih sesuai dan dibutuhkan klien sesuai dengan kondisinya (here and now). Perawat juga menilai diri sendiri, apakah kemampuan interpersonal, intelektual, tekhnikal sesuai dengan tindakan yang akandilaksanakan, dinilai kembali apakah aman bagi klien. Setelah semuanya tidak ada hambatan maka tindakan keperawatan boleh dilaksanakan (Fadillah, 2021). 
Implementasi dilakukan sesuai intervensi keperawatan pada klien dengan perilaku kekerasan dengan melihat kemampuan kognitif, afektif dan psikomotor klien. Tehnik yang perlu diperhatikan adalah strategi komunikasi, yang harus dilakukan yaitu : bersikap tenang, bicara lambat, bicara tidak dengan cara menghakimi, bicara netral dengan cara yang kongkrit, tunjukkan respek pada klien, hindari intensitas kontak mata langsung, demonstrasikan cara mengontrol situasi tanpa kesan berlebihan, fasilitasi pembicaraaan klien, dengarkan klien, jangan terburu-buru menginterpretasikan, jangan buat janji yang tidak dapat perawat sejati. Lingkungan: menyediakan berbagai aktivitas. Tindakan perilaku: membuat kontrak dengan klien mengenai perilaku yang dapat diterima.

\subsection{Evaluasi}

Evaluasi adalah proses hasil atau sumatif dilakukan dengan membandingkan respon klien pada tujuan umum dan tujuan khusus yang telah ditentukan. Risiko perilaku kekerasan pendengaran tidak terjadi perilaku kekerasan, klien dapat membina hubungan saling percaya, klien dapat mengenal Risiko perilaku kekerasannya, klien dapat mengontrol Risiko perilaku kekerasan dari jangka waktu 4x24 jam didapatkan data subjektif keluarga menyatakan senang karena sudah diajarkan teknik mengontrol Risiko perilaku kekerasan, keluarga menyatakan pasien mampu melakukan beberapa teknik mengontrol Risiko perilaku kekerasan. Data objektif pasien tampak berbicara sendiri saat Risiko perilaku kekerasan itu datang, pasien dapat berbincang- bincang dengan orang lain, pasien mampu melakukan aktivitas terjadwal, dan minum obat secara teratur ( Aji, 2019). Evaluasi keperawatan yang diharapkan: klien sudah dapat mengidentifikasi penyebab, frekuensi perilaku kekerasan dan mengontrol perilaku kekerasan dengan Tarik nafas dalam dan pukul kasur atau bantal, klien tidak melakukan perilaku kekerasan, klien minum obat dengan benar dan teratur. 


\section{BAB 3}

\section{TINJAUAN KASUS}

\subsection{Pengkajian}

\section{Identitas}

$\begin{array}{ll}\text { Inisial } & : \text { Tn. H } \\ \text { Jenis kelamin } & : \text { Laki-Laki } \\ \text { Umur } & : \text { Tahun } \\ \text { Agama } & : \text { Kristen Prostestan } \\ \text { Status } & : \text { Jl. Simanetek Dr. Norsila Kec. Ajibata } \\ \text { Alamat } & : \text { Status klien dan komunikasi dengan klien. } \\ \text { Tanggal pengkajian } & \text { 26 Januari 2022 } \\ \text { Informant } & \end{array}$

\subsection{Alasan Masuk Rumah Sakit}

Alasan klien masuk RSJ. Prof. Dr. Muhammad Ildrem jiwa adalah klien mengatakan klien sering marah-marah, melempar barang yang ada dirumahnya, klien mengatakan pernah memukul orang sekitarnya seperti adik dan kakaknya.

\subsection{Faktor Predisposisi}

Klien sebelumnya pernah mengalami gangguan jiwa \pm 1 tahun yang lalu tepatnya pada tahun 2020 dan pulang kerumah dalam keadaan tenang. Di rumah klien tidak rutin minum obat, tidak mau kontrol penyakitnya sehingga timbul gejala-gejala tersebut. Keluarga klien tidak ada yang pernah mengalami gangguan jiwa.

Masalah Keperawatan: Risiko perilaku kekerasan 


\subsection{Fisik}

Klien tidak memiliki keluhan fisik, saat dilakukan pemeriksaan tandatanda vital, didapatkan hasil TD : 110/80 mmHg ; N : 80x/i ; P : 20x/i.

\subsection{Psikososial}

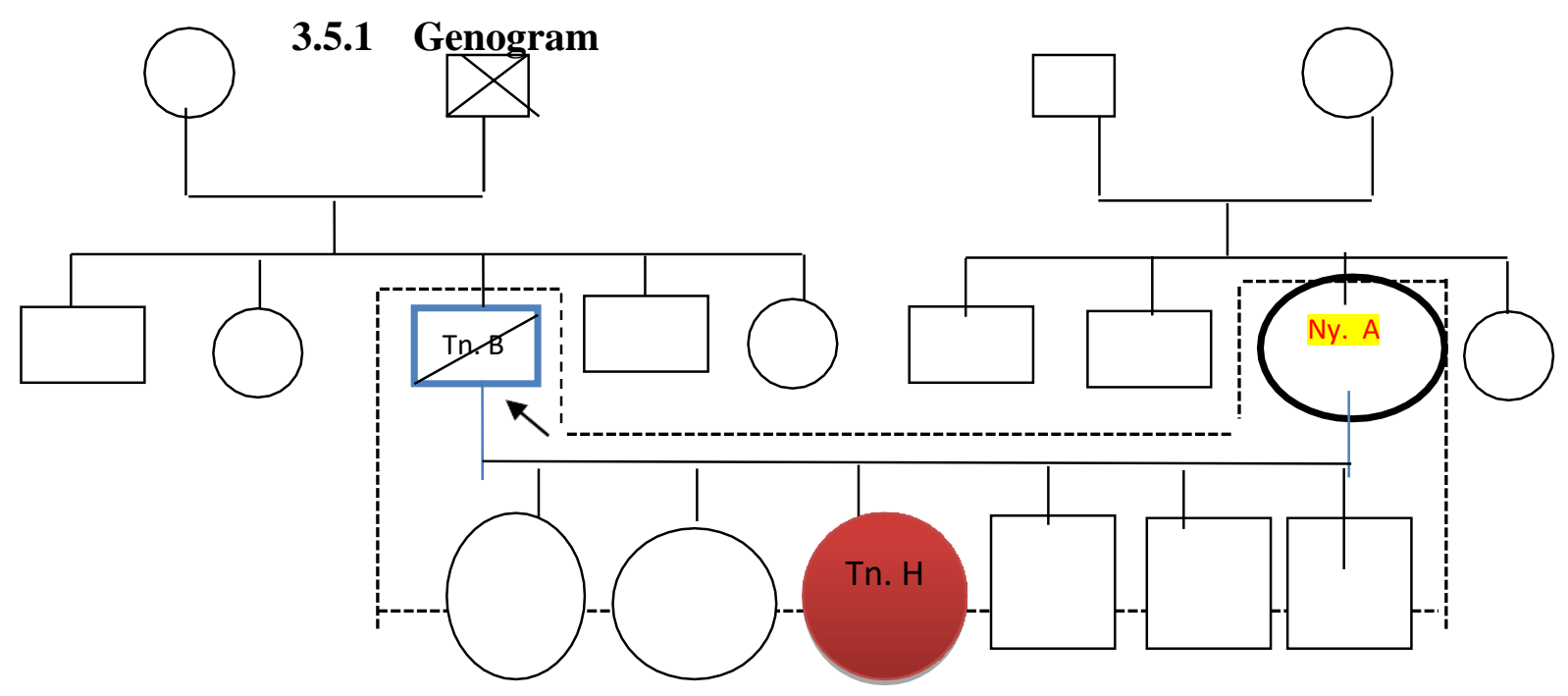

Penjelasan :

Klien anak ke tiga dari 6 bersaudara, klien berinisial Tn. H, klien anak yatim ayahnya meninggal saat dirinya berusia 12 tahun.

Keterangan :

$\square \quad$ : Perempuan

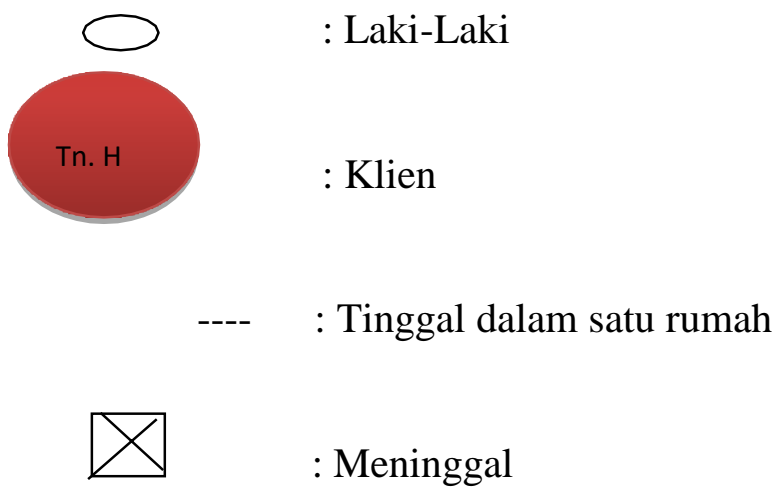




\subsubsection{Konsep diri}

a. Gambaran diri : Tidak ada kecacatan

b. Identitas : Klien anak ke 3 dari 6 bersaudara, klien hanya lulusan SMA yang saat ini dirawat di RSJ. Prof. Dr. Muhammad Ildrem medan

c. Peran : Klien berperan sebagai anak dan masih lajang, klien sebelumnya tinggal bersama keluarganya.

d. Ideal diri : Klien merasa malu karena di antarkan ke RSJ. Prof. Dr. Muhammad Ildrem.

e. Harga diri : Klien merasa apakah dirinya tidak dianggap sebagai anak lagi, karena dirinya di tempatkan jauh dari oraang tua, adik dan kakaknya

Masalah keperawatan: Gangguan konsep diri : harga diri rendah kronis

\subsubsection{Hubungan sosial}

Klien mengganggap bahwa keluarganya adalah orang yang sangat berarti dalam hidupnya, terutama orangtuanya. Klien jarang mengikuti kegiatan di RSJ. Prof. Dr. Muhammad Ildrem tersebut. Klien mengatakan suka menyendiri, tidak mau berbaur dengan kawan sekamarnya, klien juga tidak suka banyak bicara

Masalah keperawatan: Isolasi Sosial

\subsubsection{Spiritual}

a. Nilai dan Keyakinan: Klien beragama kristen dan yakin dengan agamanya. 
b. Kegiatan Ibadah

:berdoa 3 kali sehari dan setiap hari selasa mengikuti kebaktian

\subsubsection{Status Mental}

a. Penampilan

Penjelasan : Klien berpenampilan bersih, dan rapi

b. Pembicaraan

Penjelasn : klien masih mampu menjawab pertanyaan perawat dengan lambat namun dapat dipahami

c. Aktivitas Motorik

Penjelasan : Klien terlihat sedikit gelisah

d. Suasana perasaan

e. Penjelasan : Klien sedih jika melihat orang tua yang lewat depan RSJ. Prof. Dr. Muhammad Ildrem tempat klien di rawat.

Masalah keperawatan

:Harga Diri Rendah

f. Afek

Penjelasan : Afek klien labil, mudah emosi, mudah marah.

Masalah keperawatan : Risiko perilaku kekerasan

g. Interaksi selama wawancara

Penjelasan : Klien kooperatif, ada kontak mata pada lawan bicara, mudah tersinggung dalam setiap interaksi.

h. Persepsi

Penjelasan : tidak mendengar suara-suara aneh

i. Proses Pikir

Penjelasan : Klien mampu menjawab apa yang ditanya dengan baik.

j. Isi pikir 
Penjelasan : Klien dapat mengontrol isi pikirnya,klien tidak mengalami gangguan isi pikir dan tidak ada waham. Klien tidak

k. Tingkat kesadaran

Penjelasan : Klien tidak mengalami gangguan orientasi, klien mengenali waktu, orang dan tempat.

I. Memori

Penjelasan : Klien mampu menceritakan kejadian di masa lalu dan yang baru terjadi.

m. Tingkat konsentrasi berhitung

Penjelasan : Klien mampu berkonsentrasi dalam perhitungan sederhana tanpa bantuan orang lain.

n. Kemampuan penilaian

Penjelasan : Klien dapat membedakan hal yang baik dan yang buruk.

o. Daya tilik diri

Penjelasan : Klien tidak mengingkari penyakit yang diderita, klien mengetahui bahwa dia sering marah.

\subsection{Mekanisme Koping}

Klien mengalami mekanisme koping adaptif yaitu klien dapat berbicara baik dengan orang lain dan berkooperatif.

\subsection{Masalah Psikososial dan Lingkungan}

Klien mengatakan terpaksa mengikuti kegiatan di RSJ. Prof. Dr. Muhammad Ildrem tersebut.

\subsection{Pengetahuan Kurang Tentang Gangguan Jiwa}

Klien tidak mengetahui tentang gangguan jiwa yang di alaminya dan klien tau apa obat yang dikonsumsinya. 
3.9 Analisis Data

\begin{tabular}{|l|l|c|}
\hline No & \multicolumn{1}{|c|}{ Data } & Masalah Keperawatan \\
\hline 1 & Subjektif : & Risiko Perilaku \\
& $\begin{array}{l}\text { Klien mengatakan pernah melempar } \\
\text { barang-barang yang ada dirumahnya,pernah } \\
\text { memukul keluarganya dan marah- marah } \\
\text { kepada adiknya. }\end{array}$ & \\
& $\begin{array}{l}\text { Objektif : } \\
\text { Klien tampak memandang orang lain } \\
\text { dengan tatapan bermusuhan dan tampak } \\
\text { gelisah. }\end{array}$ & \\
\hline
\end{tabular}

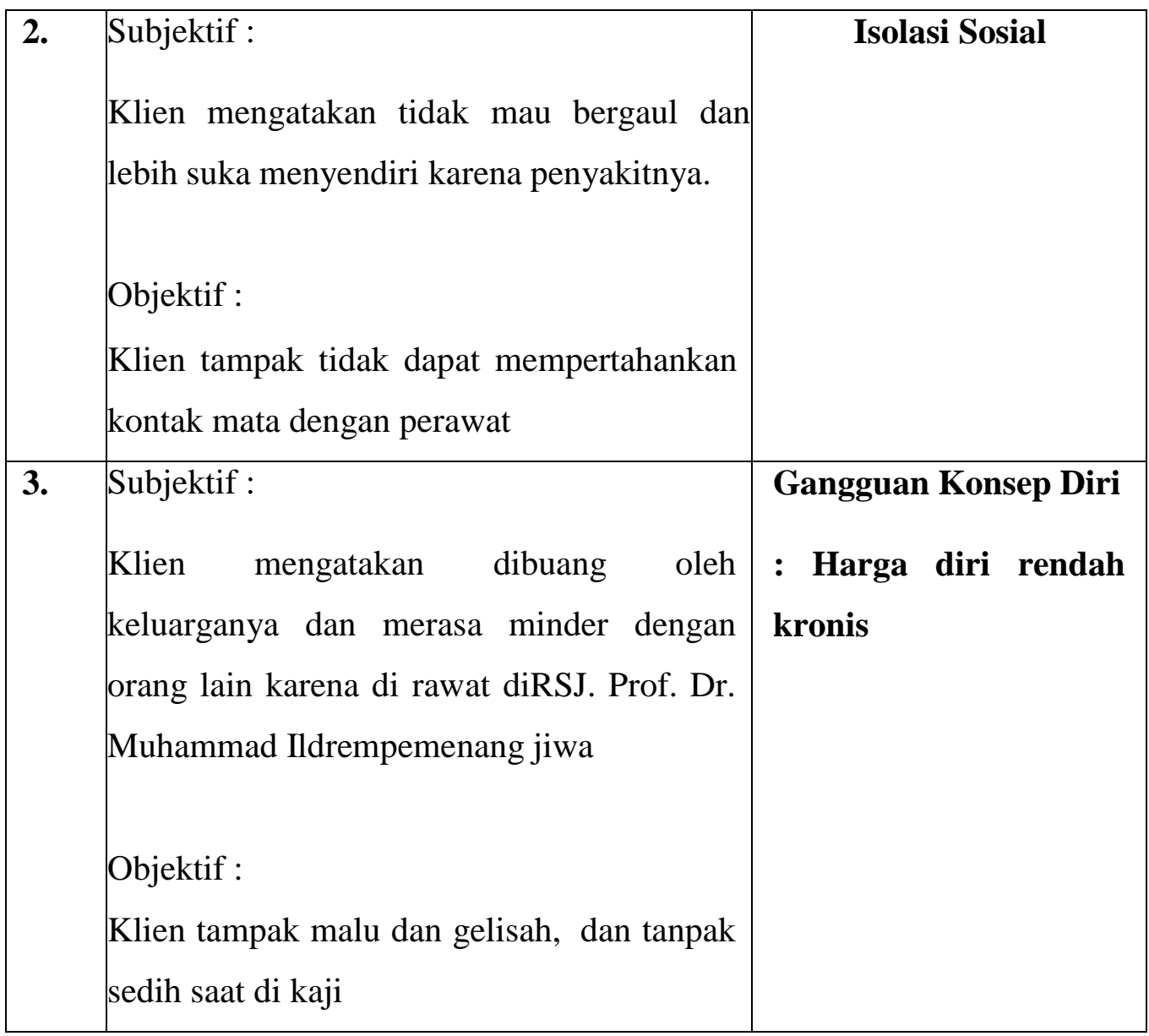




\subsection{Daftar Masalah Keperawatan}
a. Risiko Perilaku Kekerasan
b. Isolasi Sosial
c. Gangguan Konsep Diri : Harga Diri Rendah kronis

\subsection{Pohon Masalah}

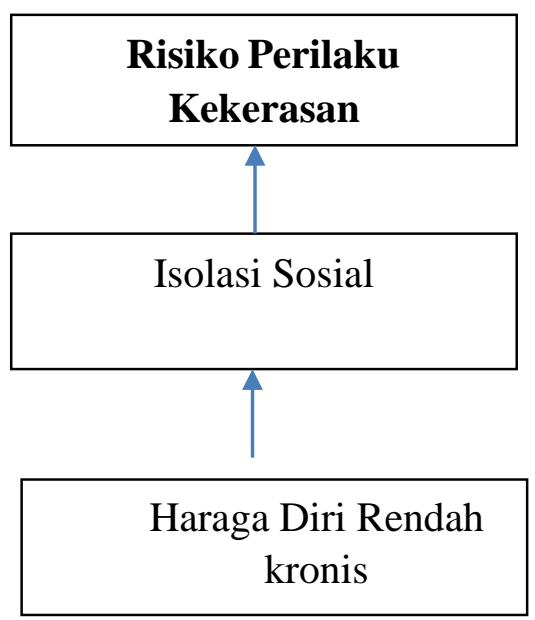

\subsection{Diagnosa Prioritas}

- Risiko Perilaku Kekerasan

\subsection{Intervensi Keperawatan}

\begin{tabular}{|c|c|c|c|}
\hline $\begin{array}{l}\text { Diagnosa } \\
\text { Keperawatan }\end{array}$ & Tujuan & Kriteria Hasil & Intervensi \\
\hline $\begin{array}{l}\text { Risiko perilaku } \\
\text { kekerasan }\end{array}$ & $\begin{array}{l}\text { klien dapat } \\
\text { mebina hubungan } \\
\text { saling percaya }\end{array}$ & $\begin{array}{l}\text { Ketika di evaluasi } \\
\text { Klien mau membalas } \\
\text { salam, } \\
\text { berjabat } \\
\text { menyebutkan } \\
\text { tersenyum, nama, }\end{array}$ & $\begin{array}{l}\text { 1.1.Membina } \\
\text { hubungan } \\
\text { salin } \\
\text { perca ya } \\
\text { dengan } \\
\text { cara }\end{array}$ \\
\hline
\end{tabular}




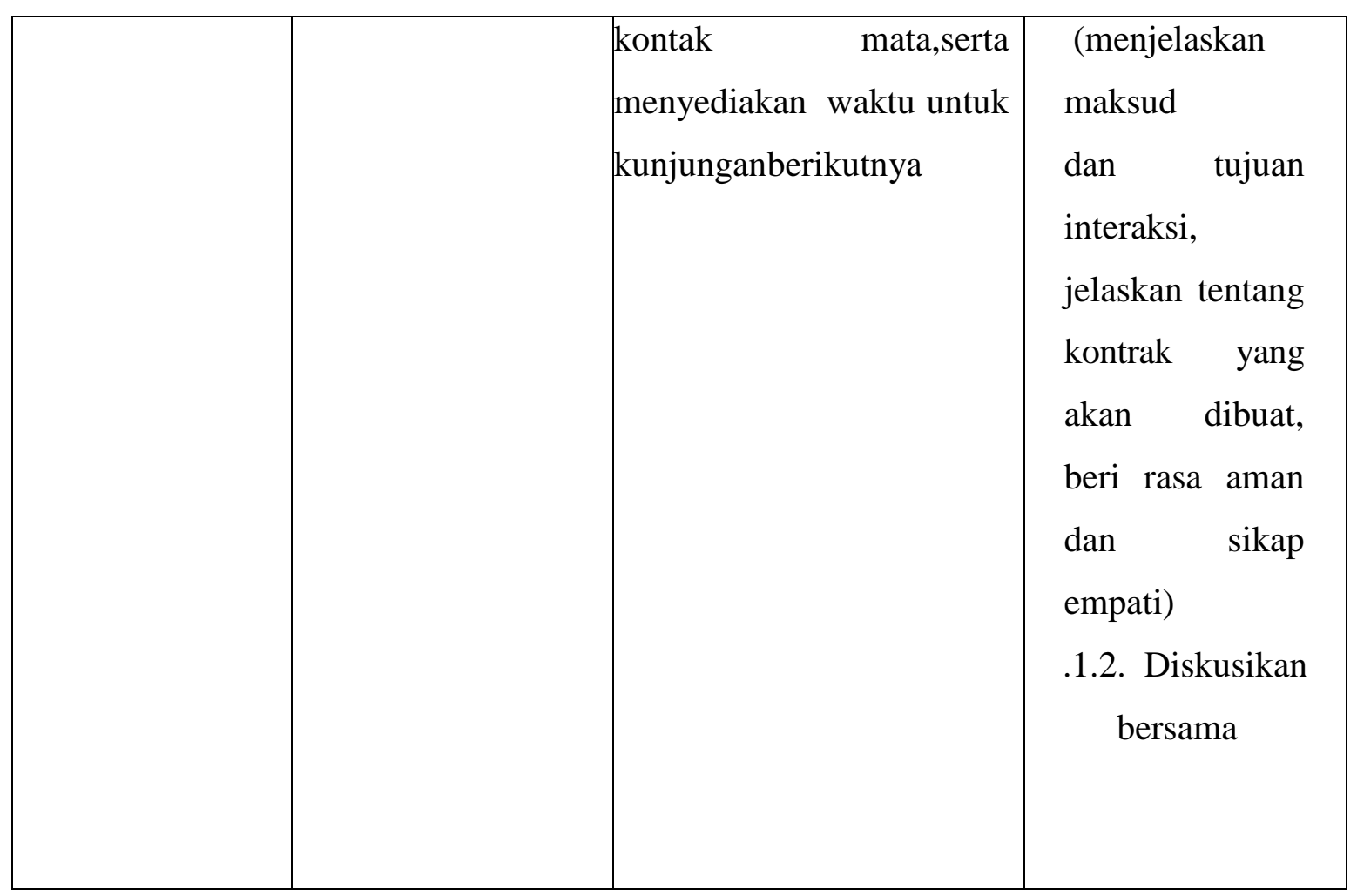

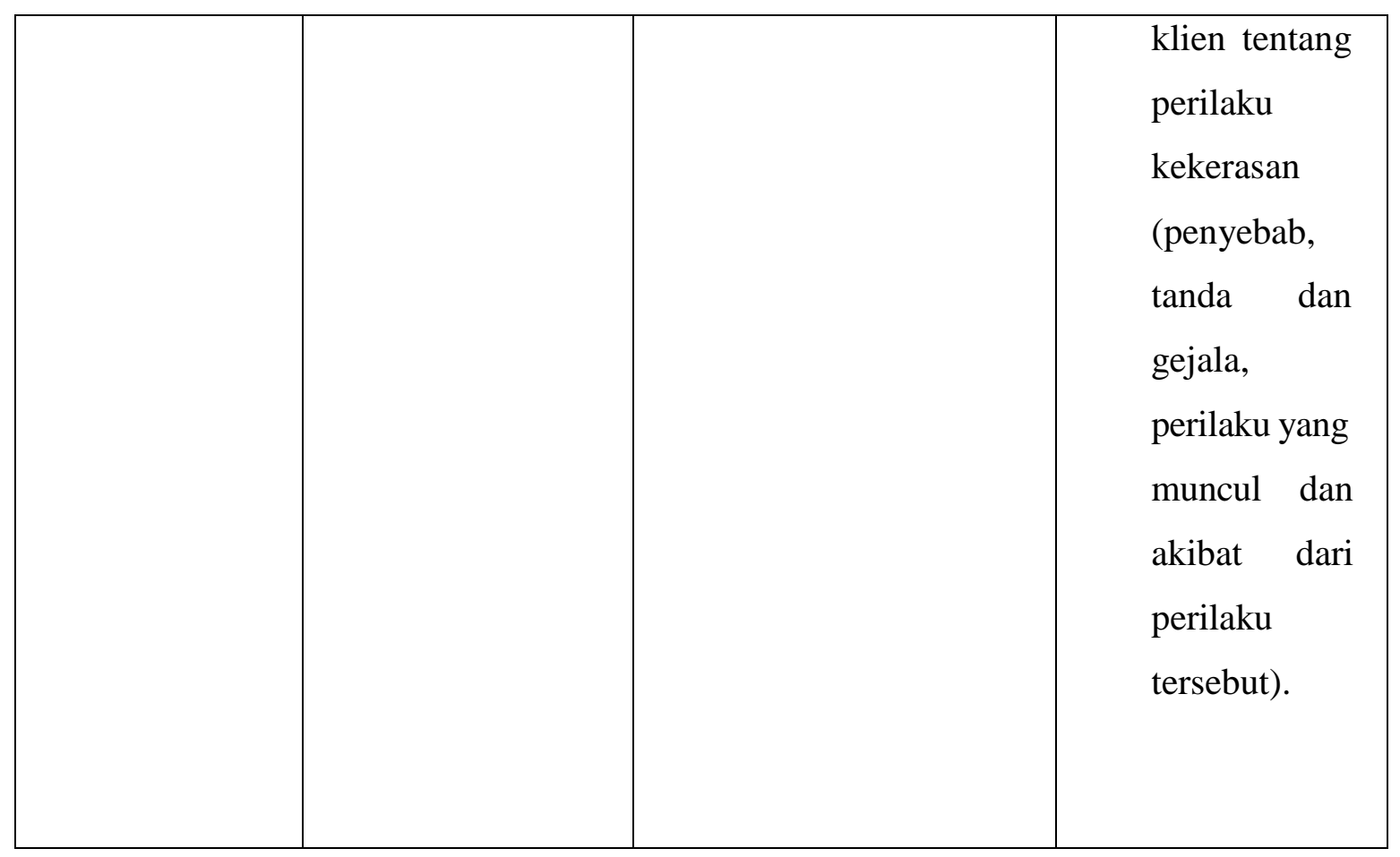




\begin{tabular}{|c|c|c|}
\hline 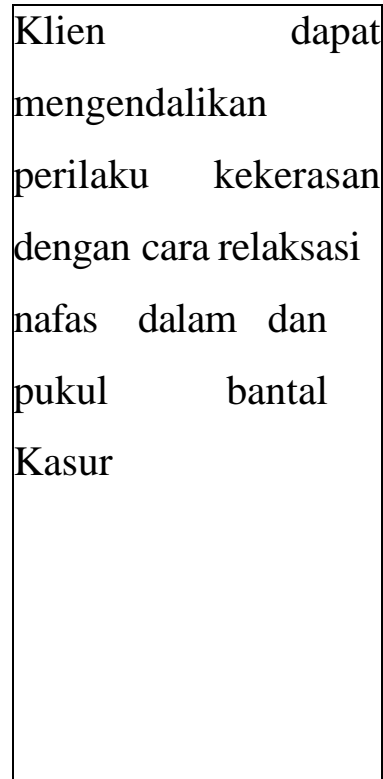 & 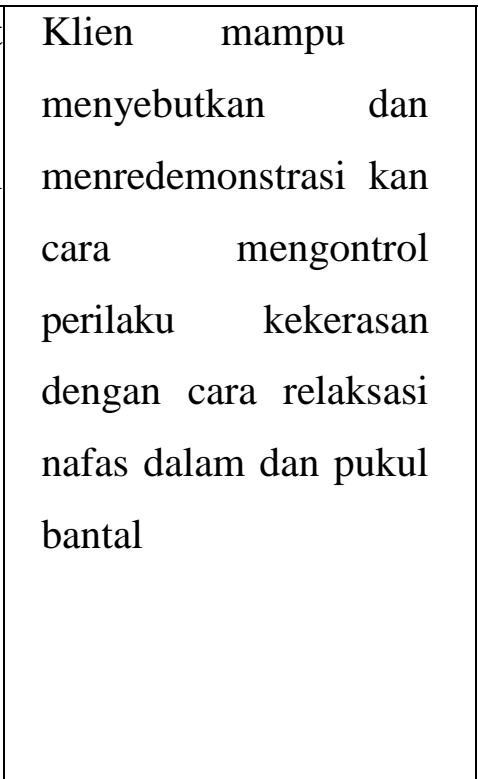 & $\begin{array}{l}\text { Sp } 1 \\
\text { Latih klien } \\
\text { melakukan } \\
\text { cara } \\
\text { mengontrol } \\
\text { Kemarahan: } \\
\text { 1. Ajarkan } \\
\text { tehnik } \\
\text { relaksasi } \\
\text { nafas dalam } \\
\text { 2. Pukul bantal }\end{array}$ \\
\hline $\begin{array}{l}\text { Klien dapat } \\
\text { mengendalikan } \\
\text { perilaku } \\
\text { kekerasandengan } \\
\text { minum obat } \\
\text { secara } \\
\text { teratur }\end{array}$ & $\begin{array}{l}\text { Klien mampu } \\
\text { mengendalikan perilaku } \\
\text { kekerasan dengan minum } \\
\text { obat }\end{array}$ & $\begin{array}{l}\text { Sp 2: } \\
\text { Bantu klien } \\
\text { mengontrol } \\
\text { perilaku kekerasan } \\
\text { pasien dengan } \\
\text { minum obat secara } \\
\text { Teratur }\end{array}$ \\
\hline $\begin{array}{l}\text { klien paham dan } \\
\text { mampu } \\
\text { mengendalikan } \\
\text { risiko perilaku } \\
\text { kekerasan } \\
\text { dengan cara } \\
\text { berbicara dengan } \\
\text { baik }\end{array}$ & $\begin{array}{l}\text { Klien paham dan mampu } \\
\text { menyampaikan amarah } \\
\text { dengan cara berbicara } \\
\text { dengan baik }\end{array}$ & $\begin{array}{l}\text { Lakukan SP } 3 \\
\text { pasien risiko } \\
\text { perilaku } \\
\text { kekerasan } \\
\text { Ajarkan kepada } \\
\text { klien bicara yang } \\
\text { baik bila sedang } \\
\text { marah. Ada tiga } \\
\text { cara: } \\
\text { - Meminta } \\
\text { dengan }\end{array}$ \\
\hline
\end{tabular}




\begin{tabular}{|c|c|c|c|}
\hline & & & $\begin{array}{l}\text { baik tanpa } \\
\text { marah } \\
\text { - Menolak } \\
\text { dengan } \\
\text { baik } \\
\text { - Mengungka } \\
\text { pkan } \\
\text { perasaan } \\
\text { kesal }\end{array}$ \\
\hline & 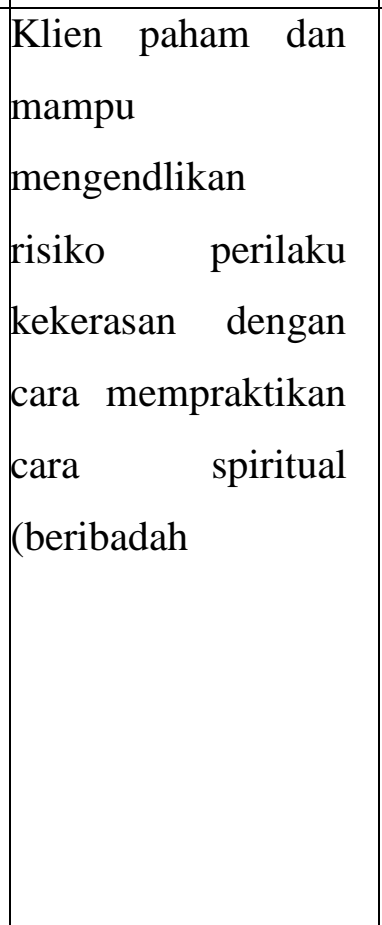 & $\begin{array}{l}\text { Klien paham dan } \\
\text { mampu } \\
\text { mengendalikan risiko } \\
\text { perilaku kekerasan } \\
\text { dengancara beribadah }\end{array}$ & $\begin{array}{l}\text { Lakukan SP } 4 \\
\text { pasien risiko } \\
\text { perilaku } \\
\text { kekerasan : } \\
\text { Diskusikan } \\
\text { bersama klien } \\
\text { cara } \\
\text { mengendalik } \\
\text { an risiko } \\
\text { perilaku } \\
\text { kekerasan } \\
\text { dengan cara } \\
\text { beribadah. }\end{array}$ \\
\hline Isolasi Sosial & $\begin{array}{l}\text { Klien dapat } \\
\text { melaksanakan } \\
\text { hubungan sosial } \\
\text { secara bertahap }\end{array}$ & $\begin{array}{l}\text { Klien } \\
\text { melaksanakan } \\
\text { hubungan sosial secara } \\
\text { bertahap setelah 3x } \\
\text { interaksi dengan : } \\
\text { a) Klien - perawat } \\
\text { b) Klien - perawat- } \\
\text { perawat lain } \\
\text { c) Klien - perawat- } \\
\text { perawat lain } \\
\text { - klien lain } \\
\text { Klien - } \\
\text { keluarga atau } \\
\text { kelompok } \\
\text { masyarakat atau }\end{array}$ & $\begin{array}{l}\text { 4.1 Observasi } \\
\text { perilaku klien } \\
\text { saat } \\
\text { berhubungan } \\
\text { dengan orang } \\
\text { lain } \\
\text { 4.2 Beri motivasi } \\
\text { dan bantu klien } \\
\text { untuk } \\
\text { berkenalan atau } \\
\text { berkomunikasi } \\
\text { dengan orang } \\
\text { lain melalui : } \\
\text { a. Klien - } \\
\text { perawat }\end{array}$ \\
\hline
\end{tabular}




\begin{tabular}{|c|c|c|c|}
\hline & & & $\begin{array}{cc}\text { b. } & \text { Klien- } \\
\text { perawat } & - \\
\text { perawat lain } \\
\text { c. Klien } \\
\text { keluarga } \\
\text { atau } \\
\text { kelompok } \\
\text { 4.3 Beri } \\
\text { reinforcement } \\
\text { terhadap } \\
\text { keberhasilan } \\
\text { yang telah } \\
\text { dicapai } \\
\text { 4.4 Bantu klien } \\
\text { mengevaluasi } \\
\text { manfaat } \\
\text { berhubungan } \\
\text { dengan orang } \\
\text { lain } \\
\text { 4.5 Motivasi dan } \\
\text { libatkan klien } \\
\text { untuk mengikuti } \\
\text { kegiatan TAK } \\
\text { sosialisasi }\end{array}$ \\
\hline $\begin{array}{l}\text { Harga } \\
\text { Diri Rendah }\end{array}$ & $\begin{array}{l}\begin{array}{l}\text { Klien } \\
\text { berinteraksi } \\
\text { orang lain. }\end{array} \\
\text { dengan } \\
\text { Klien rrampu } \\
\text { membina hubungan } \\
\text { saling percaya }\end{array}$ & $\begin{array}{l}\text { - Klien dapat menerima } \\
\text { kehadiran perawat } \\
\text { setelah 3x pertemuan } \\
\text { - Klien dapat } \\
\text { mengungkapkan } \\
\text { perasaan dan } \\
\text { keberdayaan saat ini } \\
\text { secara verbal } \\
\text { a) Klien mau menjawab } \\
\text { salam } \\
\text { b) Ada kontak mata } \\
\text { c) Klien mau berjabat } \\
\text { tangan } \\
\text { d) Klien mau berkenalan } \\
\text { e) Klien mau menjawab } \\
\text { pertanyaan } \\
\text { f) Klien mau } \\
\text { g) Klien } \\
\text { mampu } \\
\text { mengungkapkan } \\
\text { perasaannya. }\end{array}$ & $\begin{array}{ll}\text { 1. Bina hubungan } \\
\text { saling percaya } \\
\text { dengan : } \\
\text { a. } & \text { Sapa klien } \\
& \text { dengan } \\
& \text { ramah baik } \\
& \text { verbal } \\
& \text { maupun non } \\
& \text { verbal } \\
\text { b. } & \text { Perkenalkan } \\
\text { c. } & \text { Tanyakan } \\
\text { d. } & \text { Jelaskan } \\
\text { e. } & \text { Buat } \\
& \text { kontrak } \\
& \text { interaksi } \\
& \text { yang jelas, } \\
& \text { jujur dan } \\
& \text { tepati janji } \\
\text { f. } & \text { Tunjukkan } \\
\text { g. } & \text { Beri } \\
& \text { perhatian } \\
& \text { pada klien } \\
\text { dan }\end{array}$ \\
\hline
\end{tabular}




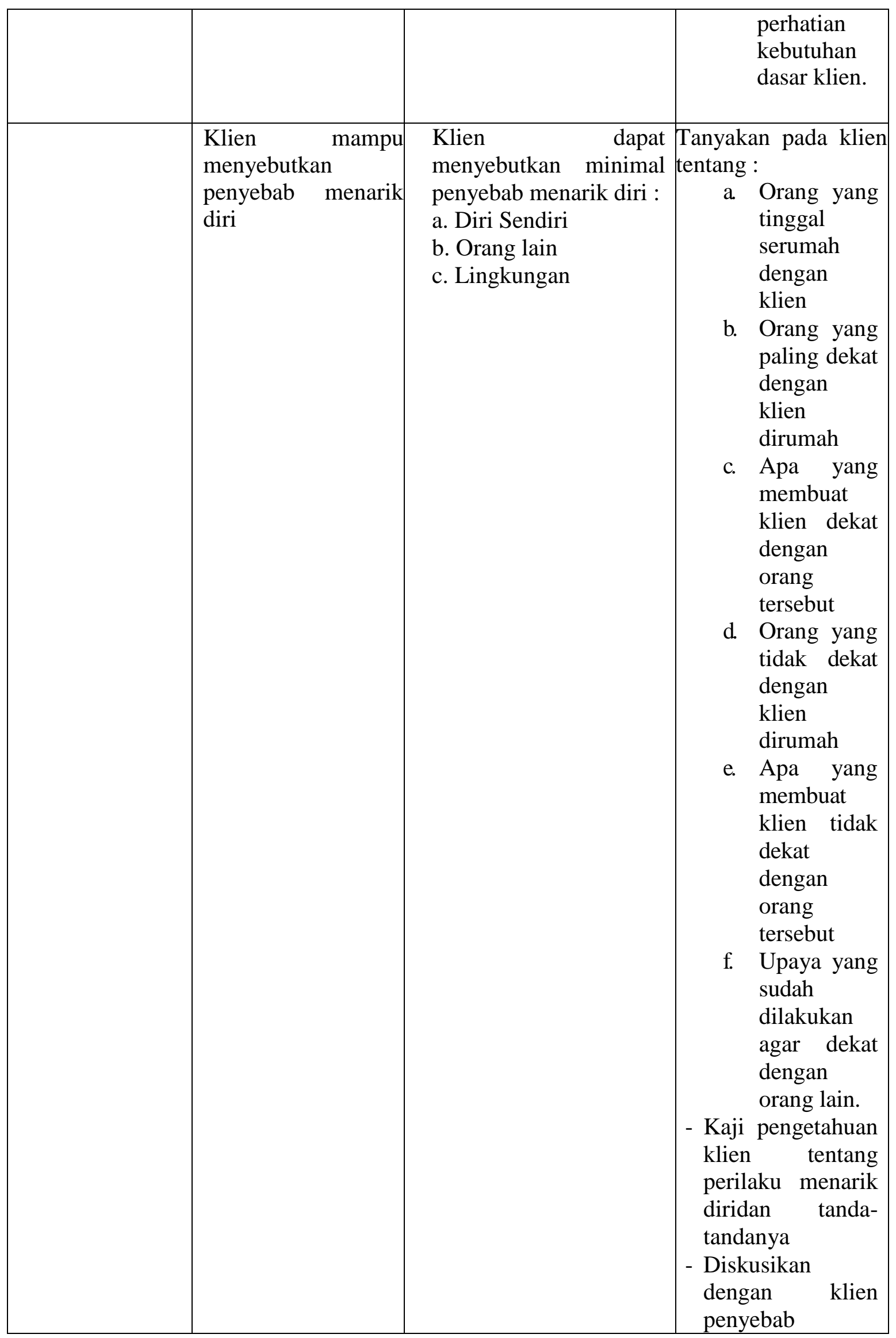




\begin{tabular}{|l|l|l|}
\hline & & $\begin{array}{l}\text { menarik diri atau } \\
\text { tidak mau bergaul } \\
\text { dengan orang lain } \\
- \text { Beri pujian } \\
\text { terhadap } \\
\text { kemampuan klien } \\
\text { mengungkapkan } \\
\text { perasaannya. }\end{array}$ \\
& & \\
& & \\
& & \\
& & \\
\end{tabular}


3.14 Implementasi Dan Evaluasi Keperawatan

\begin{tabular}{|c|c|c|}
\hline Hari/tgl & Implementasi & Evaluasi \\
\hline $\begin{array}{l}\text { Rabu 26-01- } \\
2022 \\
14: 00-15: 30\end{array}$ & $\begin{array}{l}\text { Data : } \\
\text { Tanda dan gejala : mudah marah- } \\
\text { marah, mudah tersinggung,tatapan } \\
\text { sinis, ,suka menyendiri, merasa tidak } \\
\text { dihargai } \\
\text { TTV : } \\
\text { TD : 170/70 mmHg } \\
\text { RR: 22x/i } \\
\text { Diagnosa Keperawatan Risiko } \\
\text { Perilaku Kekerasan } \\
\text { 1. } \text { Tindakan keperawatan: } \\
\text { Sp 1Risiko PerilakuKekerasan: } \\
\text { - Mengidentifikasi penyebab risiko } \\
\text { perilaku kekerasan yaitu jika } \\
\text { kemauan klien tidak dituruti } \\
\text { Mengidentifikasi tanda dan gejala } \\
\text { risiko perilaku kekerasan yaitu } \\
\text { klien marah, mengamuk tanpa } \\
\text { jelas, merusak barang-barang, dan } \\
\text { cenderung melukai orang lain } \\
\text { Menyebutkan cara mengontrol } \\
\text { risiko perilaku kekerasan adalah } \\
\text { dengan latihan fisik 1: tarik napas } \\
\text { dalam latihan fisik } 2: \text { pukul kasur } \\
\text { bantal } \\
\text { Membantu klien latihan tarik } \\
\text { napas dalam dan pukul kasur } \\
\text { bantal. } \\
\text { Sp2 Risiko Perilaku Kekerasan: } \\
\text { - Mengontrolrisiko perilaku } \\
\quad \text { kekerasan dengan minum obat } \\
\quad \text { secara teratur }\end{array}$ & 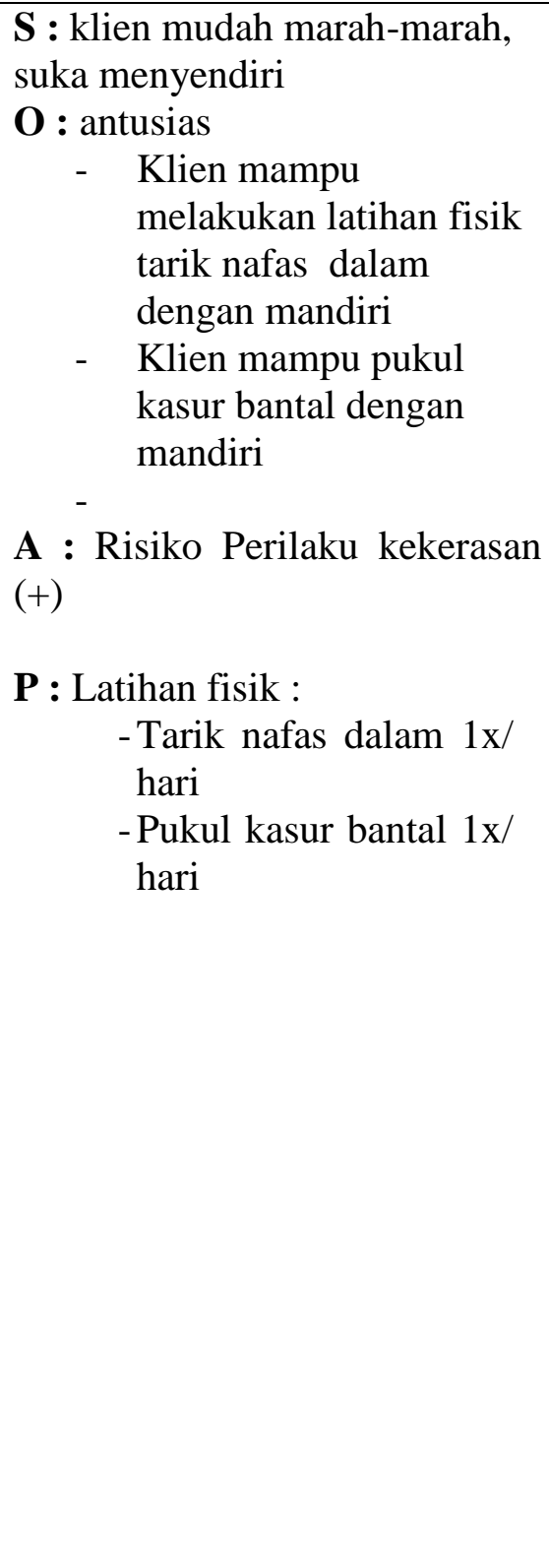 \\
\hline $\begin{array}{l}\text { Kamis 27-01- } \\
2022 \\
14: 00-15-30\end{array}$ & $\begin{array}{l}\text { Data : } \\
\text { Tanda dan gejala : mudah marah- } \\
\text { marah, mudah tersinggung,tatapan } \\
\text { sinis, merasa tidak dihargai } \\
\text { TTV: } \\
\text { TD: } 160 / 80 \mathrm{mmHg} \\
\text { RR : } 20 x / 1 \\
\text { Diagnosa Keperawatan Risiko } \\
\text { Perilaku Kekerasan } \\
\text { Tindakan keperawatan: }\end{array}$ & $\begin{array}{l}\text { S : klien masih sering marah- } \\
\text { marah tanpa sebab, dan suka } \\
\text { menyendiri. } \\
\begin{array}{ll}\mathrm{O}: & \\
& \text { Klien mampu } \\
& \text { melakukan tarik nafas } \\
& \text { dalam dengan mandiri } \\
- & \text { Klin mampu pukul kasur } \\
& \text { bantal secara mandiri } \\
\text { - } & \text { Klien mampu ke poli }\end{array}\end{array}$ \\
\hline
\end{tabular}




\begin{tabular}{|c|c|c|}
\hline & $\begin{array}{l}\text { Sp 2Risiko Perilaku Kekerasan } \\
\text { 1. } \text { Mengevaluasi kemampuan } \\
\text { klienuntuk tarik nafas dalam dan } \\
\text { pukul kasur bantal } \\
\text { 2. Memberikan informasi tentang } \\
\text { penggunaan obat } \\
\text { 2.RTL: } \\
\text { Sp } 3 \text { Risiko Perilaku Kekerasan } \\
\text { - Komunikasi secara } \\
\text { verbal:Asertif/bicara baik-baik. }\end{array}$ & 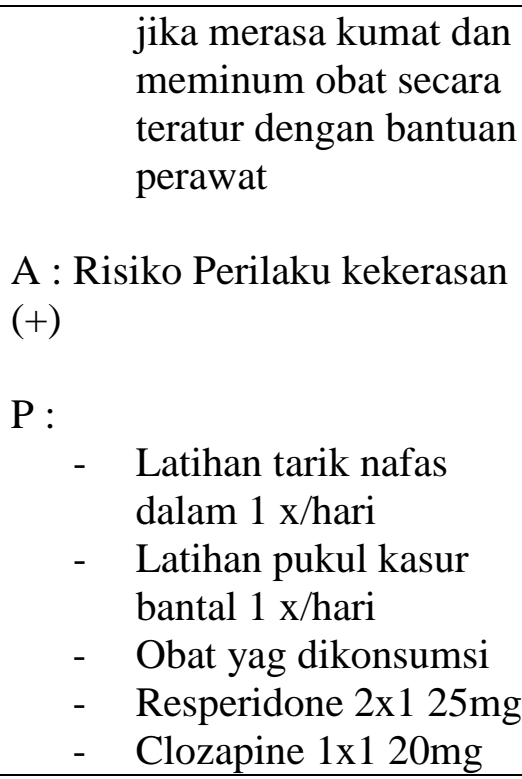 \\
\hline $\begin{array}{l}\text { Jumat 28-01- } \\
2022 \\
14: 00-15: 30\end{array}$ & $\begin{array}{l}\text { 1. Data : } \\
\text { Tanda dan gejala : mudah marah- } \\
\text { marah, mudah tersinggung,tatapan } \\
\text { sinis, merasa tidak dihargai } \\
\text { TTV: } \\
\text { TD: } 175 / 60 \mathrm{mmHg} \\
\text { RR: } 22 x / \mathrm{i}\end{array}$ & $\begin{array}{l}\text { S : senang dan antusias } \\
\mathbf{O}: \\
\text { - Klien mampu melakukan } \\
\text { komunikasi secara verbal : } \\
\text { asertif/bicara secara mandiri } \\
\text { dengan motivasi }\end{array}$ \\
\hline
\end{tabular}

\begin{tabular}{|c|c|c|}
\hline & $\begin{array}{l}\text { Diagnosa Keperawatan: } \\
\text { Risiko Perilaku Kekerasan } \\
\text { Tindakan keperawatan: } \\
\text { Sp 3 Risiko Perilaku Kekerasan } \\
\text { - } \begin{array}{l}\text { Mengevaluasi kemampuan klien } \\
\text { untuk tarik nafas dalam dan pukul } \\
\text { kasur bantal }\end{array} \\
\text { - } \quad \text { Minum obat } \\
\text { - Komunikasi secara verbal : } \\
\text { asertif/bicara baik-baik } \\
\text { 3.RTL: } \\
\text { Sp } 4 \text { Risiko Perilaku Kekerasan: } \\
\text { - Spritual : Beribadah }\end{array}$ & $\begin{array}{l}\text { A : Risiko Perilaku kekerasan } \\
(+) \\
\text { P :- Latihan tarik nafas dalamdan } \\
\text { pukul kasur bantal 1x/hari } \\
\text { Klien melakukan komunikasi } \\
\text { secaraverbal : asertif/bicara baik- } \\
\text { baik }\end{array}$ \\
\hline
\end{tabular}




\begin{tabular}{|c|c|c|}
\hline $\begin{array}{l}\text { SABTU 29- } \\
01-2022 \\
14: 00-15: 30\end{array}$ & $\begin{array}{l}\text { Data : } \\
\text { Tanda dan gejala : mudah marah- } \\
\text { marah, mudah tersinggung,tatapan } \\
\text { sinis, merasa tidak dihargai } \\
\text { Diagnosa Keperawatan: Risiko } \\
\text { Perilaku Kekerasan } \\
\text { Tindakan keperawatan: } \\
\text { Sp 4 Risiko Perilaku Kekerasan } \\
\text { - Mengevaluasi kemampuan klien } \\
\text { dalam tarik nafas dalam dan pukul } \\
\text { kasur bantal, minum obat secara } \\
\text { teratur dan bicara baik- baik. } \\
\text { - Melatih klien untuk melaksanakan } \\
\text { kegiatan spiritual yang sudah diatur }\end{array}$ & $\begin{array}{l}\text { S : senang. } \\
\text { O :-senang dan antusias } \\
\text { Klien mampu melaksanakan } \\
\text { kegiatan ibadah dengan mandiri } \\
\text { misalnya Sholat } \\
\text { A : Risiko perilaku kekerasan (+) } \\
\text { P: } \\
\text { Latihan tarik nafas dalamdan } \\
\text { pukul kasur bantal 2x/hari } \\
\text { Latihan melakukan } \\
\text { komunikasi secara verbal : } \\
\text { asertif/bicara mandiri dengan } \\
\text { motivasi }\end{array}$ \\
\hline
\end{tabular}

\begin{tabular}{|c|c|c|}
\hline & $\begin{array}{l}\text { RTL : } \\
\text { Risiko Perilaku Kekerasan : Follow up } \\
\text { dan evaluasi SP 1-4 risiko Perilaku } \\
\text { Kekerasan }\end{array}$ & $\begin{array}{l}\text {-Latihan klien untuk } \\
\text { melaksanakan kegiatanspiritual } \\
\text { yang sudah diatur. }\end{array}$ \\
\hline $\begin{array}{l}\text { Kamis } \\
\text { 03-02-2022 } \\
\text { 14:00-17:00 }\end{array}$ & $\begin{array}{l}\text { Data: } \\
\text { Tanda dan gejala : tidak mau berbicara } \\
\text { jika tidak ada yang duluan mengajak } \\
\text { bicara, wajah sedih, murung, pendiam, } \\
\text { dan suara pelan } \\
\text { TD: } 160 / 85 \mathrm{mmHg} \\
\text { RR: 20x/i } \\
\text { Diagnosa Keperawatan } \\
\text { Gangguan Konsep Diri : Harga } \\
\text { diri rendah kronis } \\
\text { 1. Tindakan Keperawatan } \\
\text { SP 1 : Gangguan Konsep Diri } \\
\text { : Harga diri rendah kronis } \\
\text { 1. Mengidentifikasi kemampuan } \\
\quad \text { dan aspek positif yang dimiliki } \\
\text { pasien } \\
\text { SP 2 : Gangguan Konsep Diri } \\
\text { : Harga diri rendah kronis } \\
\text { 2. Menilai kemampuan yang }\end{array}$ & $\begin{array}{l}\text { S : Klien mengatakan senang, } \\
\text { dan antusias } \\
\text { O : } \\
\text { - } \text { Klien sudah mampu } \\
\text { memgidentifikasi aspek } \\
\text { postif yang ada pada } \\
\quad \text { dirinya: klien pandai } \\
\quad \text { menggambar dengan } \\
\quad \text { mandiri } \\
\text { - } \quad \text { Klien sudah mampu } \\
\quad \text { menetapkan kemapuan } \\
\quad \text { yang dapat digunakan } \\
\text { A : } \\
\text { Gangguan Konsep Diri : Harga } \\
\text { diri rendah kronis (+) } \\
\text { P : } \\
\text { - Latiham aspek positif yang } \\
\text { dimiliki klien 1x/hari } \\
\text { - Latih klien untuk }\end{array}$ \\
\hline
\end{tabular}




\begin{tabular}{|c|c|c|}
\hline \begin{tabular}{|l} 
Jum'at \\
$04-02-2022$ \\
14:00- 17:30
\end{tabular} & $\begin{array}{l}\text { Data : Tanda dan gejala : merasa tidak } \\
\text { berguna, tidak mau berbicara jika tidak } \\
\text { ada yang duluan mengajak bicara, wajah } \\
\text { sedih, murung, pendiam, dan suara } \\
\text { pelan, jika diajak bicara klien menunduk } \\
\text { Diagnosa keperawatan : Harga } \\
\text { diri rendah kronis } \\
\text { Tindakan keperawatan: } \\
\text { SP } 3 \text { : Gangguan Konsep Diri : } \\
\text { Harga diri rendah kronis } \\
\text { Melatih kegiatan sesuai kemampuan } \\
\text { yang dipilih } \\
\text { SP } 4 \text { : Gangguan Konsep Diri } \\
\text { : Harga diri rendah kronis } \\
\text { Melatih kegiatan sesuai } \\
\text { kemampuan yang di pilih } 3 \\
\text { SP } 4 \text { : Gangguan Konsep Diri } \\
\text { : Harga diri rendah kronis } \\
\text { - Melatih kegiatan sesuai } \\
\text { kemampuan yang di pilih } \\
\text { - Klien dilatih cara meningkatkan } \\
\text { aspek positif yang dimilikinya } \\
\text { Diagnosa Keperawatan }\end{array}$ & $\begin{array}{l}\text { S : Pasien sangat antusias } \\
\text { O : Pasien mampu menjelaskan } \\
\text { hal-hal yang disukai dia seperti : } \\
\text { menggambar, mewarnai, } \\
\text { bernyanyi dengan mandiri dan } \\
\text { motivasi } \\
\text { A : Gangguan Konsep Diri : } \\
\text { Harga diri rendah kronis (+) } \\
\text { P : } \\
\text { latihan berinteraksi dengan orang } \\
\text { lain dengan cara menggambar } \\
\text { untuk mempererat interaksi } \\
\text { sosialnya sesuai kemampuan } \\
\text { positif yang dimiliki } 1 \text { x/sehari. }\end{array}$ \\
\hline
\end{tabular}




\begin{tabular}{|c|c|c|}
\hline & $\begin{array}{l}\text { Gangguan Konsep Diri : Harga diri } \\
\text { rendah } \\
\text { Tindakan Keperawatan SP 1 : } \\
\text { Gangguan Konsep Diri : } \\
\text { Harga diri rendah kronis } \\
\text { 1. Mengidentifikasi kemampuan } \\
\text { dan aspek positif yang dimiliki } \\
\text { pasien } \\
\text { SP 2 : Gangguan Konsep Diri } \\
\text { : Harga diri rendah kronis } \\
\text { - Menilai kemampuan yang dapat } \\
\quad \text { digunakan menetapkan/ memilih } \\
\quad \text { kegiatan sesuai kemampuan. } \\
\text { - Melatih kegiatan sesuai kemampuan } \\
\quad \text { yang dipilih 1 } \\
\text { SP 3 : Gangguan Konsep Diri } \\
\text { : Harga diri rendah kronis } \\
\text { Melatih kegiatan sesuai kemampuan } \\
\text { yang dipilih } 2 \\
\text { SP 4 : Gangguan Konsep Diri } \\
\text { : Harga diri rendah kronis } \\
\text { Melatih kegiatan sesuai kemampuan } \\
\text { yang di pilih } 3\end{array}$ & $\begin{array}{l}\text { dipilih 2: mewarnai } \\
\text { 2) Latihan kegiatan yang } \\
\text { dipilih } 3: \text { bernyanyi } \\
\text { 3) Latiha menyusun jadwal } \\
\text { untuk melakukan kegiatan } \\
\text { yang sudah dilatih }\end{array}$ \\
\hline $\begin{array}{l}\text { Senin } 06 \\
\text { Februari } 2022 \\
10: 30\end{array}$ & $\begin{array}{l}\text { Data : } \\
\text { Klien mengatakan tidak mau berbaur } \\
\text { dengan teman sekamarnya } \\
\text { Klien tampak menyendiri. } \\
\text { Diagnosa Keperawatan : Isolasi Sosial } \\
\text { Tindakan Keperawatan } \\
\text { SP 1-2 Isolasi sosial } \\
\text { - Menjelaskan keuntungan dan } \\
\quad \text { kerugian memiliki teman } \\
\text { - Melatih klien berkenalan dengan } 2 \\
\quad \text { orang atau lebih }\end{array}$ & $\begin{array}{l}\text { S: klien bersemangat dan } \\
\text { antusias dalam mengikuti } \\
\text { terapi lanjutan yang diberikan } \\
\text { secara mandiri dengan } \\
\text { motivasi } \\
\text { O: } \\
\text { 1. klien tampak menyendiri } \\
\text { 2. klien tidak nampak bergaul } \\
\text { dengan teman disekitar } \\
\text { ruangan klien } \\
\text { 3. klien tidak bisa } \\
\text { menyebutkan kembali } \\
\text { keuntungan berinteraksi } \\
\text { dengan orang lain } \\
\text { A: Isolasi Sosial (+) } \\
\text { P: } \\
\text { 1 menjelaskan keuntungan } \\
\text { dan kerugian memiliki } \\
\text { teman }\end{array}$ \\
\hline
\end{tabular}




\begin{tabular}{|c|c|c|}
\hline & & $\begin{array}{l}2 \text { isolasi sosial yaitu } \\
\text { melatih klien cara } \\
\text { berkenalan dengan } 2 \text { orang } \\
\text { atau lebih }\end{array}$ \\
\hline $\begin{array}{l}\text { Selasa } 07 \\
\text { Februari } 2022 \\
10: 40\end{array}$ & $\begin{array}{l}\text { Data : } \\
\text { Tanda dan gejala: sudah mau berbaur } \\
\text { dengan teman sekamarnya, dan klien } \\
\text { sudah mampu berkomunikasi dengan } \\
\text { orang lain } \\
\text { TTV: } \\
\text { TD: } 150 / 80 \mathrm{mmHg} \\
\text { RR : 20x/i } \\
\text { Diagnosa Keperawatan : Isolasi Sosial } \\
\text { Tindakan Keperawatan: } \\
\text { SP 3-4 Isolasi sosial } \\
\text { - latihan bercakap-cakap sambal } \\
\text { melakukan kegiatan harian } \\
\text { - melatih berbicara sosial : memint } \\
\quad \text { sesuatu berbelanja dan sebagiannya }\end{array}$ & $\begin{array}{l}\text { S: senang dan antusian } \\
\text { klien mengatakan tau } \\
\text { keuntungan berintraksi dengan } \\
\text { orang lain secara mandiri } \\
\text { O: - klien tampak sudah bisa } \\
\text { berkenalan dengan 1 orang } \\
\text { - } \quad \text { klien mampu menyebutkan } \\
\text { keuntungan berkenalan } \\
\quad \text { dengan orang lain. } \\
\text { A: Isolasi Sosial } \\
\text { P: } \\
\quad \text { - melatih klien melakukan } \\
\quad \text { kegiatan harian } \\
\text { - melatih klien berbicara } \\
\text { sosial : meminta sesuatu } \\
\text { berbelanja dan sebagainya } \\
\text { - }\end{array}$ \\
\hline
\end{tabular}




\section{BAB 4}

\section{PEMBAHASAN}

\subsection{Tahap Pengkajian}

Selama pengkajian dilakukan pengumpulan data dari beberapa sumber yaitu dari pasien dan pengawai Rumah Sakit Jiwa. Mahasiswa mendapat sedikit kesulitan dalam menyimpulkan data kerena keluarga pasien jarang mengkunjungi pasien di RS. Jiwa. Prof. Dr. Muhammad Ildrem. Maka mahasiwa melakukan pendekatan pada pasien melalui komunikasi terapautik yang lebih terbuka membantu pasien untuk memecahkan perasaannya dan juga melakukan observasi kepada pasien. Adapan upaya tersebut yaitu :

a. Melakukan pendekatan dan membina hubungan saling percaya diri pada pasien agar pasien lebih terbuka dan lebih percaya dengan menggunakan perasaan.

b. Mengadakan pengkajian pasien dengan wawancara dan tidak menemukan kesenjangan karena di temukan hal sama seperti diteori bahwasanya Perilaku kekerasan merupakan respon maladaptif dari kemarahan, hasil dari kemarahan yang ekstrim ataupun panik. Perilaku kekerasan yang timbul pada klien skizofrenia diawali dengan adanya perasaan tidak berharga, takut,dan ditolak oleh lingkungan sehingga individu akan menyingkir dari hubungan interpersonal dengan oran lain (Pardede, Keliat \& Yulia, 2015).

\subsection{Tahap perencanaan}

Perencanaan dalam proses keperawatan lebih dikenal dengan rencana asuhan keperawatan yang merupakan tahap selanjutnya setelah pangkajian dan penentuan diagnosa keperawatan. Pada tahap perencanaan penulis.hanya menyusun rencana tindakan keperawatan sesuai dengan pohon masalah keperawatan yaitu :perilaku kekerasan, isolasi sosial, dan harga diri rendah kronis. Pada tahap ini antara 
tinjauan teoritis dan tinjaun kasus tidak ada kesenjangan sehingga penulis dapat melaksanakan tindakan seoptimal mungkin dan didukung dengan seringnya bimbingan dengan pembimbing. Secara teoritis digunakan cara strategi pertemuan sesuai dengan diagnosa keperawatan yang muncul saat pengkajian. Adapun upaya yang dilakukan penulis yaitu :

\section{Risiko Perilaku Kekerasan}

a. Mengidentifikasi isi Risiko Perilaku Kekerasan

b. Mengidentifikasi waktu terjadi Risiko Perilaku Kekerasan

c. Mengidentifikasi situasi pencetus Risiko Perilaku Kekerasan

d. Mengidentifikasi respon terhadap Risiko Perilaku Kekerasan

e. Membantu pasien mempraktekan latihan cara mengontrol RisikoPerilaku Kekerasan dengan tarik napas dalam dan pukul kasur bantal

f. Menjelaskan cara mengontrol perilaku kekerasan dengan minum obat secara teratur, oabat yang dikonsumsi yaitu: Resperidone 2x1 25mg, Clozaphine 1x1 20mg

g. Melatih pasien mengontrol Risiko Perilaku Kekerasan denganberbicara baik-baik dengan orang lain dan spritual

h. Mengevaluasi jadwal kegiatan harian pasien

2. Isolasi Sosial
a. Menjelaskan keuntungan dan kerugian memiliki teman
b. Melatih klien berkenalan dengan 2 orang atau lebih
c. Melatih bercakap-cakap sambil melakukan kegiatan harian
d. Melatih berbicara sosial : meminta sesuatu berbelanja, dan sebagiannya.

3. Harga Diri Rendah Kronis
a. Mengidentifikasi kemampuan positif yang dimiliki pasien
b. Menilai/menetapkan kemampuan yang dapat digunakan
c. Melatih kegiatan sesuai kemampuan 1 yaitu : menggabar 

d. Melatih kegiatan sesuai kemampuan 2 yaitu : mewarnai
e. Melatih kemampuan yang dipilih 3 yaitu : bernyanyi

\subsection{Tahap Implementasi}

Pada tahap implementasi, penulis hanya mengatasi 3 masalah keperawatan yakni: diagnosa keperawatan Risiko Perilaku Kekerasan, Isolasi Sosial, dan Harga Diri Rendah Kronis. Pada diagnosa keperawatan Risiko Perilaku Kekerasan dilakukan strategi pertemuan yaitu mengidentifikasi Perilaku Kekerasan, mengontrol perilaku kekerasan dengan cara tarik napas dan pukul kasur bantal. Strategi pertemuan yang kedua yaitu anjurkan minum obar secara teratur, strategi pertemuan ketiga yaitu latihan dengan cara komunikasi secara verbal atau bicara baik-baik strategi pertemuan ke empat yaitu Spritual. Diagnosa Keperawatan yang kedua Harga Diri Rendah Kronis dilakukan strategi pertemuan yaitu mengidentifikasi kemampuan dan aspek positif yang dimiliki pasien. Strategi pertemuan kedua menilai kemampuan yang dapat digunakan, menetapkan /memilih kegiatan sesuai kemampuan, melatih kegiatan sesuai kemampuan yang dipilih 1 . Strategi pertemuan ketiga melatih kegiatan sesuai kemampuan yang dipilih 2. Strategi pertemuan keempat melatih kegiatan sesuai kemampuan yang dipilih 3. Diagnosa Keperawatan ketiga Isolasi Sosial dilakukan strategi pertemuan yaitu menjelaskan keuntungan dan kerugian mempunyai teman. Strategi pertemuan kedua melatih klien berkenalan dengan 2 orang atau lebih. Strategi pertemuan ketiga melatih bercakap cakap sambil melakukan kegiatan harian. Strategi pertemuan keempat melatih berbicara sosial; meminta sesuatu berbelanja dan sebagainya.

\subsection{Tahap evaluasi}

Pada tinjauan teoritis evaluasi yang diharapkan adalah :

1. Pasien sudah dapat mempercayai perawat sebagai terapis

2. Sudah bisa mengidentifikasi dan mengontrol Risiko Perilaku 


\section{Kekerasan}

3. Dapat mengendalikan Risiko Perilaku Kekerasan melalui latihan fisik,

4. Dapat mengendalikan Risiko Perilaku Kekerasan dengan cara minumobat secara teratur

5. Dapat mengendalikan Risiko Perilaku Kekerasan dengan berbicara baik-baik

6. Dapat mengendalikan Risiko Perilaku Kekerasan dengan spritual yangterjadwal.

7. Sudah mampu menjelaskan keuntungan dan kerugian memiliki teman

8. Sudah dapat berkenalan dengan 2 orang atau lebih

9. Dapat melaukan kegiatan harian

10. Dapat berbicara sosial seperti meminta sesuatu berbelanja atau sebagiannya

11. Dapat menggembangkan aspek positif yang dimiliki

12. Dapat memilih dan menilai kemampuan yang dapat digunakan sesuai yang dipilih pasien. 


\section{BAB 5}

\section{PENUTUP}

\subsection{Kesimpulan}

1. Pengkajian

Pada tahap pengkajian ini didapatkan ada kesenjangan dari tinjauan kasus pada Tn. H mahasiwa melakukan pendekatan pada pasien melalui komunikasi terapautik yang lebih terbuka membantu pasien untuk memecahkan perasaannya dan juga melakukan observasi kepada pasien.

2. Diagnosa keperawatan

Dari pengkajian yang didapat ada 3 masalah keperawatan yang mucul yaitu Risiko Perilaku Kekerasan, Isolasi Sosia, Harga diri rendah kronis.

3. Intervensi Keperawatan

Setelah ditegakkan diagnose keperawatan, penulis menyusun perencanaan yaitu, membina hubungan saling percaya antara perawat dan klien, dan memberikan terapi Sp 1-4 pada resiko perilaku kekerasan, Sp 1-4 Isolasi Sosial, Sp 1-4 Harga Diri Rendah Kronis Sp yang diberikan 1x sehari pada klien

4. Implementasi Keperawatan

Setelah menyusun perencanaan keperawatan selanjutnya penulis memberikan dan menjelaskan terapi Sp Risiko perilaku kekerasan, Isolasi sosial, dan Harga diri rendah kronis.

5. Evaluasi Keperawatan

Setelah menguraikan tentang proses keperawatan pada Tn. $\mathrm{H}$ dan dapat disimpulkan bahwa pasien dapat mengontrol perilaku kekerasan, dapat bersosialisasi dengan baik, dan beranggapan bahwa dirinya berarti. Dengan terapi yang diajarkan oleh penulis, pasien dapat melakukan terapi Sp mulai dari Sp : Risiko perilaku kekerasan, Isolasi sosial dan Harga diri rendah kronis. 


\subsection{Saran}

1. Bagi Keluarga

Diharapkan pada keluarga sering mengunjungi pasien selama waktu perawatan karena dengan seringnya keluarga berkunjung, maka pasien merasa berarti dan dibutuhkan dan juga setelah pulang keluarga harus memperhatikan obat dikonsumsi seta membawa pasien kontrol secara teratur kepelayana kesehatan jiwa ataupun rumah sakit jiwa.

2. Bagi institusi pendidikan

Bagi institusi pendidikan terkait, diharapkan hasil asuhan keperawatan jiwa ini dapat menjadi bahan atau materi pembelajaran baik kalangan mahasiswa pendidikan sarjana maupun profesi agar dapat melaksanakan asuhan keperawatan jiwa mengenai masalah resiko perilakun kekerasan dapat menjadi lebih baik lagi.

3. Bagi Rumah Sakit Jiwa

Dapat memberikan pelayanan kesehatan lebih baik lagi, khususnya bagian mental/jiwa. 


\section{DAFTAR PUSTAKA}

1. Azis, N. R., Sukamto, E., \& Hidayat, A. (2018). Pengerun Terapi DeEkslasi Terhadap Perubahan Perilaku Pasien dengan Risiko perilaku kekerasan di Rumah Sakit Jiwa Daerah Atma Husada Mahakam Samarinda. http://repository.poltekkes-kaltim.ac.id/id/eprint/797

2. Estika, M. W, E. (2021). Asuhan Keperawatan Jiwa Pada Pasien Dengan Risiko Perilaku Kekerasan di Rumah Sakit Daerah dr Arif Zainuddin Surakarta (Doctoral dissertation, Universitas Kusuma Husada Surakarta). http://eprints.ukh.ac.id/id/eprint/1020

3. Pardede, J. A. (2022). Koping Keluarga Tidak Efektif Dengan Pendekatan Terapi Spesialis Keperawatan Jiwa.

4. Pardede, J. A. (2020). Ekspresi emosi keluarga yang merawat pasien skizofrenia. Jurnal ilmiah keperawatan Imelda, 6(2), 117-122.

5. Fadillah, F. (2021). Studi Kasus: Asuhan Keperawatan Jiwa Pada Ny. R Dengan Risiko Perilaku Kekerasan.

6. Hastuti, R. Y., Agustina, N., \& Widiyatmoko, W. (2019). Pengaruh restrain terhadap penurunan skore panss EC pada pasien skizofrenia dengan perilaku kekerasan. Jurnal Keperawatan Jiwa, 7(2), 135-144. https://jurnal.unimus.ac.id/index.php/JKJ/article/view/4907/pdf

7. Hasannah, S. U. (2019). Asuhan Keperawatan Jiwa pada Pasien Dengan Risiko Perilaku Kekerasan (Doctoral dissertation, STIKes Kusuma Husada Surakarta).

8. Pardede, J. A. (2019). Health Education of Drinking Medication Adherence on Schizophrenia Patients. Journal of Psychiatry, 2(2), 723.

9. Keliat, B.A \& Akemat (2016). Keperawatan jiwa : terapi Aktivitas kelompok. Ed.2. EGC

10. Kio, A. L., Wardana, G. H., \& Arimbawa, A. G. R. (2020). Hubungan Dukungan Keluarga terhadap Tingkat Kekambuhan Klien dengan Risiko perilaku kekerasan. Caring: Jurnal Keperawatan,9(1), 69-72. http://ejournal.poltekkesjogja.ac.id/index.php/caring/article/view/592

11. Kemenkes RI. (2019). Riset Kesehatan Dasar, RISKESDAS.Jakarta: Kemenkes

RI.https://databoks.katadata.co.id/datapublish/2019/10/08/persebaranprevalensi-skizofreniapsikosis-di-indonesia\#

12. Makhruzah, S., Putri, V. S., \& Yanti, R. D. (2021). Pengaruh Penerapan Strategi Pelaksanaan Perilaku Kekerasan terhadap Tanda Gejala Klien Skizofrenia di Rumah Sakit Jiwa Daerah Provinsi Jambi. Jurnal Akademika Baiturrahim Jambi, 10(1), 39-46. http://dx.doi.org/10.36565/jab.v10i1.268

13. Nursaly, E., \& Damaiyanti, M. (2018). Analisis Praktik Klinik Keperawatan pada Tn. E Risiko perilaku kekerasan dengan Intervensi Inovasi Terapi Berkebun dengan Polybag terhadap Tanda-Tanda Gejala Risiko perilaku kekerasan di RSJD Atma Husada Mahakam Samarinda. https://dspace.umkt.ac.id//handle/463.2017/571

14. Pardede, J. A., \& Laia, B. (2020). Decreasing Symptoms of Risk of Violent Behavior in Schizophrenia Patients Through Group Activity 
Therapy. Jurnal Ilmu Keperawatan Jiwa,3(3), 291-300. http://journal.ppnijateng.org/index.php/jikj/article/view/621/338

15. Pardede, J. A. (2014). Pengaruh Acceptance And Commitment Therapy Dan Pendidikan Kesehatan Kepatuhan Minum Obat Terhadap Gejala, Kemampuan Berkomitmen Pada Pengobatan Dasar Kepatuhan Pasien Skizofrenia. $\quad$ https://www.researchgate.net/profile/JekAmidos/347011273.pdf

16. Pardede, J. A., Siregar, L. M., \& Halawa, M. (2020). Beban dengan Koping Keluarga Saat Merawat Pasien Skizofrenia yang Mengalami Perilaku Kekerasan. Jurnal Kesehatan, 11(2), 189-196. http://dx.doi.org/10.26630/jk.v11i2.1980

17. Pardede, J. A. (2020). Standar Asuhan Keperawatan Jiwa Dengan Masalah Risiko Perilaku. Kekerasan. Jurnal Ilmu Keperawatan Jiwa. https://doi.org/10.31219/osf.io/we7zm

18. Pardede, J. A., Simanjuntak, G. V., \& Laia, R. (2020). The Symptoms of Risk of Violence Behavior Decline after Given Prgressive Muscle Relaxation Therapy on Schizophrenia Patients. Jurnal Ilmu Keperawatan Jiwa, 3(2), 91-100. http://dx.doi.org/10.32584/jikj.v3i2.534

19. Pardede, J. A., Siregar, L. M., \& Hulu, E. P. (2020). Efektivitas Behaviour Therapy Terhadap Risiko Perilaku Kekerasan Pada Pasien Skizofrenia Di Rumah Sakit Jiwa Prof. Dr. Muhammad Ildrem Provsu Medan. Jurnal Mutiara Ners, 3(1), 8-14. http://114.7.97.221/index.php/NERS/article/view/1005

20. Pardede, J. A., Keliat, B.A., \& Yulia, I. (2015). Kebutuhan Dan Komitmen Klien Skizofrenia Meningkat Setelah Diberkan Acceptance And Commitment Therapy Dan Pendidikan Kesehatan Kepatuhan Minum Obat. Jurnal Keperawatan Indonesia, 3(18), 157-166. http://dx.doi.org/10.7454/jki.v18i3.419

21. Pitayanti, A., \& Hartono, A. (2020). Sosialisasi Penyakit Skizofrenia Dalam Rangka Mengurangi Stigma Negatif Warga di Desa Tambakmas Kebonsari-Madiun. Journal of Community Engagement in Health, 3(2), 300-303. https://jceh.org/index.php/JCEH/article/view/83/78

22. Putri, M., Arif, Y., \& Renidayati, R. (2020). Pengaruh Metode Student Team Achivement Division Terhadap Pencegahan Perilaku Kekerasan. Media Bina Ilmia,14(10), 3317-3326. http://ejurnal.binawakya.or.id/index.php/MBI/article/view/554/pdf

23. Suerni, T., \& Livana, P. H. (2019). Respons Pasien Perilaku Kekerasan. Jurnal Penelitian Perawat Profesional, 1(1), 41-46. https://doi.org/10.37287/jppp.v1i1.16

24. Suryenti, V. (2017). Dukungan Dan Beban Keluarga Dengan Kemampuan Keluarga Merawat Pasien Risiko perilaku kekerasan Di Klinik Jiwa Rumah Sakit Jiwa Provinsi Jambi Tahun 2017. Jurnal Psikologi Jambi, 2(2), 39-46. https://www.online-journal.unja.ac.id/jpj/article/view/4795

25. WHO, (2019). Schizophrenia. Retrieved from. https://www.who.int/newsroom/fact-sheets/\%20detail/schizophrenia

26. Zahnia, S., \& Sumekar, D. W. (2016). Kajian epidemiologis skizofrenia. Jurnal Majority, 5(4), 160-166. 
27. Pardede, J. A. (2021). Standar Asuhan Keperawatan Dengan Kesiapan Peningkatan Pengetahuan.

28. Pardede, J. A. (2020). Terapi Keluarga. Jurnal Ilmiah kesehatan 